\title{
Impact of the COVID-19 Crisis on the Structure and Content of Job Advertisements
}

\author{
Bjarne Erik Roscher ${ }^{1,2,3, *}$ \\ ${ }^{1}$ Department of Business, Management and Economics, University of Latvia, Riga, Latvia \\ ${ }^{2}$ FOM University, Nürnberg, Germany \\ ${ }^{3}$ Nuremberg Institute of Technology Georg Simon Ohm, Germany
}

\begin{abstract}
Companies are more and more dependent on information technology (IT) and the buzzword digitization is present everywhere. Some companies are inventing new business models based on disruptive innovation supported by information technology. Others adapt these business models as followers. All these new business processes and underlying information technology need to be managed, serviced, and supported by IT organizations to ensure business continuity. Due to the Covid-19 pandemic in the year 2020, companies and organisations have been challenged with the fact that workers had to stay and work at home while trying to keep the operations running. This led in some companies to a digitization boost in terms of remote working, which needed new IT-Infrastructure and the adoption of business processes to function from outside the company property. In the current research, job advertisements have been analysed to investigate if the Covid-19 crisis had an impact on the focus and priorities of IT department heads. The initial assumption this research is based on is, that the content of new job openings posted on recruiting webpages in Germany would change through the influence of COVID-19. The research method was a structured content analysis of job offerings looking for IT top management positions in Germany. Data was collected at two different times in the year 2020 to reflect differences before and within the pandemic crisis. After comparing the coded keywords in both datasets no significant change in requirements of tasks or structure of the job ads can be seen in the analysis. Which leads to the conclusion that recruiting departments within companies do not really collect requirements for top management IT positions through alignment with the business. The only traces the COVID19 has left in the job adds is that in some cases home-office policies are mentioned.
\end{abstract}

Keywords: Chief Information Officer (CIO), IT Director, IT Organization, Recruitment, Covid-19 cisis

\section{Introduction}

Synnott defined 1981 the role of the chief information officer (CIO) as the "senior executive responsible for establishing corporate information policy, standards, and management control over all corporate information resources" (Synnott et al. 1981). This job title has been adapted also in other countries, among these Germany. Yet, this research 
indicates that this is mainly the case in larger enterprises while small and midsized enterprises (SME) call their IT executives "IT Leiter", "IT Manager" or "IT Abteilungsleiter". Yet also US based research show that other job titles like "IT director", "SVP/VP IT" and "IT manager" are widely used (Tallon 2014).

Many studies have shown that the role of a CIO is essential for an organization:

A CIO can positively influence the company performance not only by fostering the IT efficiency, which means lowering cost and by this increase the profit but increase the IT effectivity through improved IT use (Durst 2007).

Measures to drive IT efficiency are introducing tailored internal IT management systems (Schweda and Schmidt 2014), efficient IT service management (ITSM) frameworks (Marrone and Kolbe 2011) and the right organizational setup (Hodgkinson 1992). An efficient budgeting and controlling process which ensures that investments in technology deliver the planned results (Chan et al. 2006) is essential. Measures to improve IT effectivity are underpinning business processes with appropriate information technology (Tallon 2014).

But ultimately a CIOs main task is to ensure "Business-IT-Alignment" (BITA). This results in strategic information technology initiatives driving business performance (Peppard 2010). Major crisis events like the pandemic influence the IT strategy process. These influences must be captured in terms of the external influences and incorporated into IT strategy. (Ward and Peppard 2002)

Earlier research has shown the influence of external environment on companies and its use of information technology. Strategic use of information technology will help to tackle environmental challenges (Kim and Jee 2007; King et al. 1989). Grover and Goslar found that external factors such as market uncertainties have a positive effect on IT spending (Grover and Goslar 2015).

COVID-19 influenced IT management research touches different points. Meiler states that Covid-19 promotes digital transformation (Meiler 2020). Kumar describes how the use of "Industry 4.0" IT applications and solutions in the area of supply chain within retail industry can help the industry (Kumar et al. 2020b). Chen looks for the willingness of customers paying for IT solutions helping them with the challenges of daily life in times of the pandemic (Chen et al. 2020). Kumar gives advice on how production and operations management can be organized sustainably in times of Corona (Kumar et al. 2020a). And finally, Dwivendi et. al. gives a very compressed yet comprehensive view on Challenges within the area of information management as a collection of insights, research and recommendations (Dwivedi et al. 2020).

\section{Literature Review}

Due to the actuality of the topic described in this article, literature research found little scientific papers dealing with the topic of IT management and IT recruiting in the Covid-19 crisis. This might be the case as such a crisis with impact on so many fields of live like 
medical, social, economic, organisational, procedural and personal has not happened in the modern world which tries to compensate restrictions by digitization. This results in the fact that this article looks into the field of IT management research (Wollnik 1988; Szyperski and Winand 1989; Krcmar 1991), IT Governance research (Weill and Woodham 2002; Rüter et al. 2010; Weill and Ross 2004; Grohmann 2003); Risk management (Zellmer 1990) research only in order to set the framework. The main focus for finding CIO and IT management priorities under the current crisis are derived from official publications of "Federal Cyber Security Authority"(Bundesamt für Sicherheit in der Informationstechnik (BSI)) submitted preprints [not peer reviewed] (Mouton and Coning 2020), articles in [non-scientific] journals (Malecki 2020; Barak 2020; Faulds and Raju 2020; Furnell and Shah 2020). Yet some sparce scientific publications have also been considered in this work for general understanding of the topic of IT management in times of COVID-19 (Dwivedi et al. 2020; Kumar et al. 2020a; Chen et al. 2020; Kumar et al. 2020b; Meiler 2020), The content has not been further discussed as this work is a methodology driven analysis.

\section{Research methodology}

\subsection{Data Collection and selection}

The data collection was carried out on the following dates: a) 18.2.2020, some days before the COVID-19 pandemic started in Germany with all its measures for social distancing $\left(1^{\text {st }}\right.$ wave lockdown) and its impact on business life. b) 28.10 .2020 , right before $2^{\text {nd }}$ wave lockdown. Source for the first dataset (a) has been the internet job portals of indeed.com and linkedin.com. Source for the second dataset (b) was only indeed.com as some manual spot checks on linkedin did not generate more data.

In both cases all available job advertisements on that single day with the search words "IT Manager", "IT Leiter", "Chief Information Officer (CIO)" have been proofread to ensure that they are covering all aspects of an IT manager. In the first dataset the collection process excluded all offerings that had been published by a professional recruiter as these did not contain any information about the employer. In the second dataset these have been collected despite this missing information but later excluded in the data cleansing process executed according the PRISMA-P research methodology (Moher et al. 2015) as shown in Fig.1. 


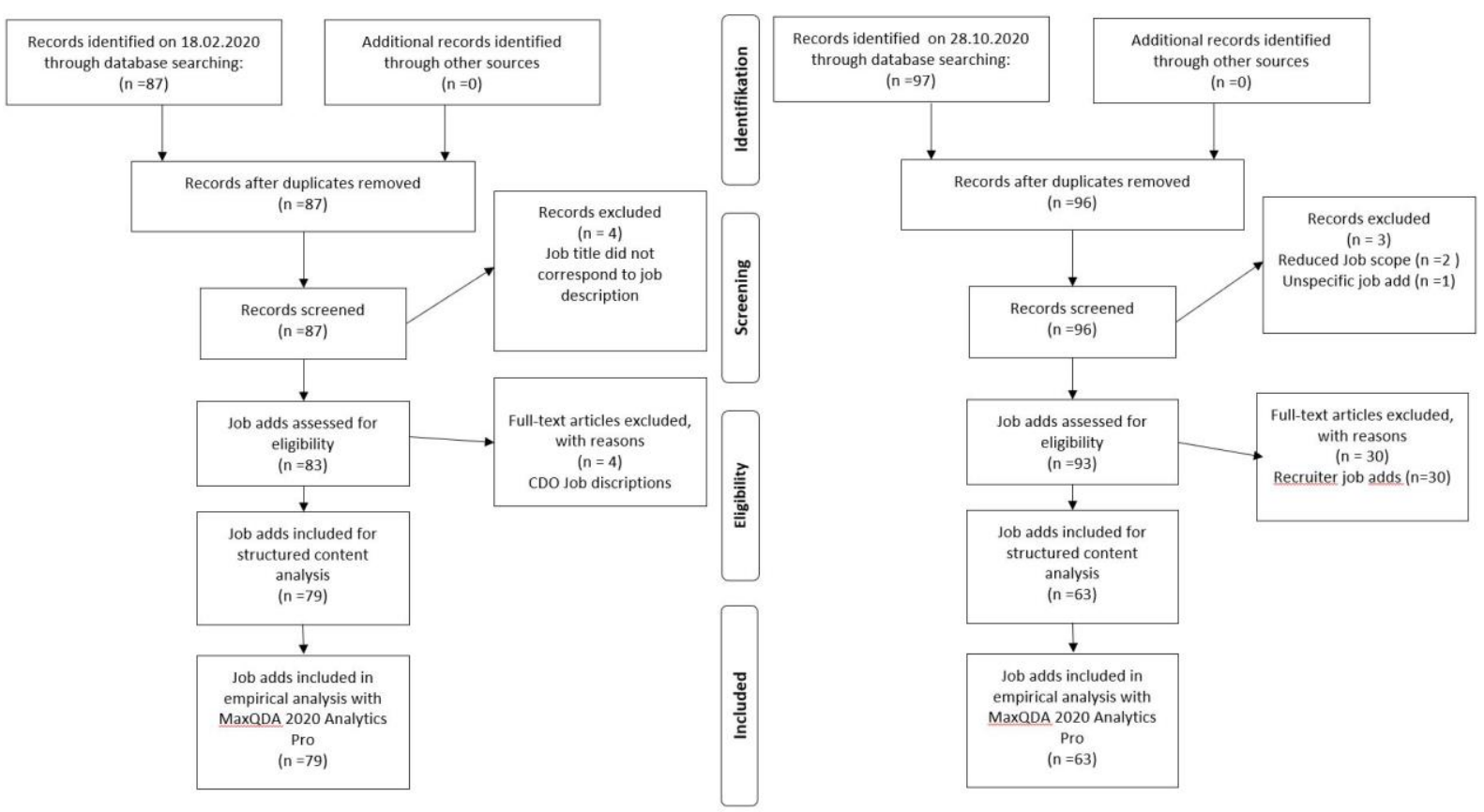

Source: author's construction based on the Prisma-P methodology (Moher et al. 2015)

\subsection{Coding}

An internet search for surveys and publications provided by management consultancy and research companies (PwC (PricewaterhouseCoopers 2020), Gartner (Sandy Shen, Owen Chen, Julian Sun, Lily Mok, Arnold Gao, Deacon D.K Wan 2020), KPMG (Bates 2020), Deloitte (Digital transformation through the lens of COVID-19 | Deloitte Insights 2020) and relevant IT management journals (ZDNet (Samuels 2020), CIO (IDG) has been conducted. The aim was to identify the top 5 priorities mentioned as measures of CIOs dealing with the challenges of the COVID-19 Crisis. The discovered priorities have been recorded without the ranking used (if any) in the surveys or texts. After generalizing the wording, a frequency analysis has been conducted which resulted in a ranking shown in Table 1. 
Table 1: Expected priorities of CIO and examples of search phrases

\begin{tabular}{|c|c|c|}
\hline CIO Priorities during and after COVID-19 & Rank (counts) & $\begin{array}{l}\text { Examples of Search phrases } \\
\text { (both german and englisch language) }\end{array}$ \\
\hline Digital collaboration & 1. $(n=4)$ & Video Conference, Heimarbeit; Homeoffice etc. \\
\hline Information Security & 2. $(n=3)$ & InfoSec, Sicherheit, Angreifer, ISO 2700, etc. \\
\hline Digitization of Business Model & 2. $(n=3)$ & Geschäftsmodel, Business Modell/Case etc. \\
\hline IT Strategy and Architecture & 2. $(n=3)$ & Strategie, Architektur, Landschaft, Planung, etc. \\
\hline Customer Interface digital enhancement & 3. $(n=2)$ & Kunden, CRM, etc. \\
\hline Data Security & 4. $(n=1)$ & Datenschutz, BDSG, DSGVo, etc. \\
\hline Ensure business continuity & 4. $(n=1)$ & Continuity, Aufrechterhaltung, etc. \\
\hline Automation & 4. $(n=1)$ & Automatisierung, Digitalisierung \\
\hline Risk Management & 4. $(n=1)$ & Compliance, Risiko \\
\hline Governance & 4. $(n=1)$ & Regeln, Gesetze, Vorschriften, Normen, etc. \\
\hline Workforce & 4. $(n=1)$ & Personalplanung, Workforce, Einsatzplanung, etc. \\
\hline Cost Control & 4. $(n=1)$ & Einsparung, Controlling, Budget, etc. \\
\hline
\end{tabular}

Source: author's calculations based on internet research

The Priorities have been translated to German language and synonyms describing these words identified. As some job offerings have been published in English language only the search phrases had to be translated back and used synchronously with the German phrases. Based on Mayrings method for content analysis, originally published in 1983(Mayring 2015), the paraphrases have been used searching the documents for sentences surrounding these words. These sentences contained further phrases which have been used to create a wordlist, which then was used for final searching within all job offerings. Finally, all found sentences have been manually read and the decision for inclusion was done due to attributes to the search phrases. Some examples show how decision was made: "Responsible for", "drive" and "contribute" are indicators for inclusion in the result list, "execute" "control", "interest in", "experience" are indicators for exclusion. For structural content analysis the software package "MAXQDA Analytics Pro 2020" has been used. 


\section{4. discussion}

The research is based on qualitative content analysis of job offerings for IT top management positions (Head of IT, IT Manager, IT Leader and CIO) in Germany collected at two points in 2020 (February and October).

\subsection{Hypothesis and Research Question}

The hypothesis for this research is:

There is an influence of economic and social impacts of Covid-19 to tasks of an IT top managers job.

The research question is:

Are changes - predicted by business research and non-scientific authors - regarding task priorities of IT managers reflected in job advertisements published 9 months after the start of the pandemic?

\subsection{Gerneral Findings (not related to the hypothesis)}

Through literature research (scientific, management, official and technical publications) the overall focus for IT departments in this early phase of the pandemic (currently 2nd wave in Germany) seems to lie in the provision of IT systems which allow collaboration from home office (Sandy Shen, Owen Chen, Julian Sun, Lily Mok, Arnold Gao, Deacon D.K Wan 2020, 2020; Bates 2020, 2020) as well as the ability to work in established business processes without coming to the office building. Information security is also seen as very essential by business consultants (PricewaterhouseCoopers 2020b; Sandy Shen, Owen Chen, Julian Sun, Lily Mok, Arnold Gao, Deacon D.K Wan 2020; Bates 2020). The "Federal Cyber Security Authority of Germany" (Bundesamt für Sicherheit in der Informationstechnik (BSI)) published a cyber security report for 2020 covering aspects and warnings induced by COVID19. The predictions and warnings have partly come true and can be read in the press, yet official statistics will only be published in the "Report on the State of IT Security in Germany 2021" next year.

Fig. 2. Job title distribution in the data collection

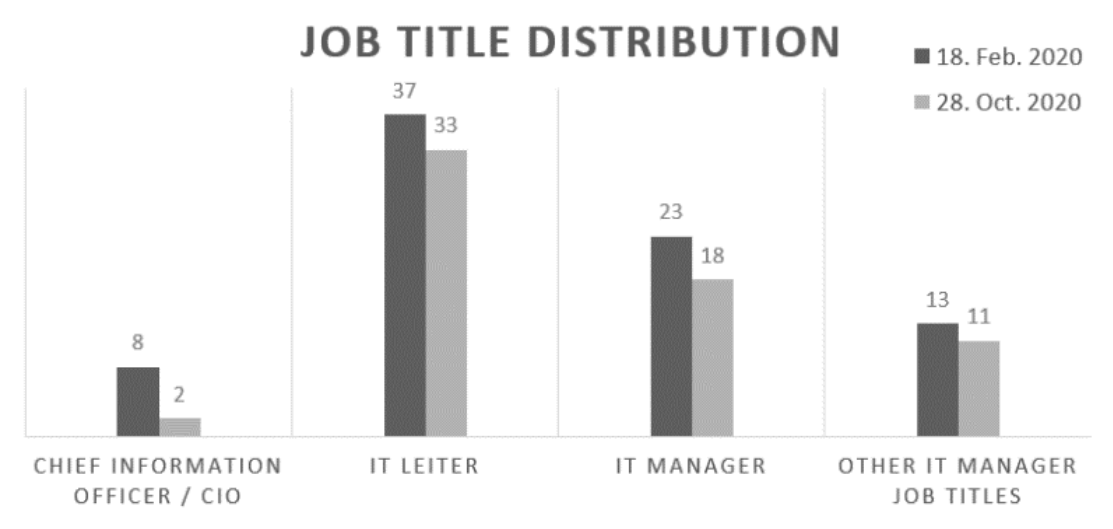

The Records could be clustered into 4 Job title groups as displayed in Fig. 2. One of the job titles has been a combination of the above which was eliminated by using one of the job titles. 
The job advertisements have been published by companies located in most regions of Germany as shown in Table 2.

Table 2: Regional distribution of job advertisements (Source - Feb. 2020: indeed \& linkedin; Oct. 2020: indeed)

\begin{tabular}{|l|c|c|c|}
\hline & \multicolumn{2}{|c|}{$\begin{array}{c}\text { Regional distribution } \\
\text { of job openings in \% }\end{array}$} & Change in \% \\
\hline German federal State & $\begin{array}{c}\text { 18th Feb. 2020 } \\
(\mathrm{n}=79)\end{array}$ & $\begin{array}{c}28 \text { th Oct. 2020 } \\
(\mathrm{n}=63)\end{array}$ & -6.3 \\
\hline Baden Würtemberg & 23.8 & 17.5 & 3.7 \\
\hline Bayern & 13.8 & 17.5 & 2.9 \\
\hline Berlin & 5.0 & 7.9 & -1.3 \\
\hline Brandenburg & 1.3 & 0.0 & 5.1 \\
\hline Bremen & 1.3 & 6.3 & -2.2 \\
\hline Hamburg & 3.8 & 1.6 & 2.7 \\
\hline Hessen & 10.0 & 12.7 & 0.0 \\
\hline Mecklemburg-Vorpommern & 0.0 & 0.0 & 0.1 \\
\hline Niedersachsen & 6.3 & 6.3 & 0.9 \\
\hline Nordrhein-Westfahlen & 15.0 & 15.9 & -3.1 \\
\hline Reinland Pfalz & 6.3 & 3.2 & 0.0 \\
\hline Saarland & 0.0 & 0.0 & -0.2 \\
\hline Sachsen & 5.0 & 4.8 & -3.8 \\
\hline Sachsen Anhalt & 3.8 & 0.0 & -0.6 \\
\hline Schleswig Hollstein & 3.8 & 3.2 & 1.9 \\
\hline Thüringen & 1.3 & 3.2 & -20.3 \\
\hline & & & 63 \\
\hline Total Number of Job Adds in Study & 79 & & \\
\hline
\end{tabular}

Source: author's calculations based on structured content analysis

Even if the amount of usable job advertisements in this study has decreased by $20 \%$ the tendency in Job title distribution and in regional distribution are similar. I conclude therefor that the data can be compared for the proposed research question.

\subsection{Alignment of findings to literature models and new IT Manager tasks}

Krcmar developed based on findings of Wollnik (Wollnik 1988)and Szyperski und Winand (Szyperski and Winand 1989) and his own research (Krcmar 1991) a 3 level model of information management. Wollniks 3 levels of information management (IM) are well established which is also represented in the mentioning in the job openings for management of applications (52) and for management of infrastructure (66). Yet the management of information seems not to be widely seen as a task for IT managers by HR departments as they are only mentioned sparsely (6). Interestingly the 4th task added in Krcmars model "Management Role of IT Organization" is not as clearly seen by employers and wide deviations in individual tasks are mentioned. The proposed subtasks from Krcmar are all 
mentioned in the set of records - yet with a medium to low frequency ( 7 to 37). All numbers are shown in Fig. 3.

Own research (Roscher 2020) has shown that Krcmars model should be extended with further tasks described in Fig.3 under "NEW Tasks". Among these are the areas of supplier coordination and IT sourcing, budgeting, IT architecture management, project management and consulting/demand-management on a top level.

Tasks of an IT Organization based on job offerings collected on 18. Feb. 2020

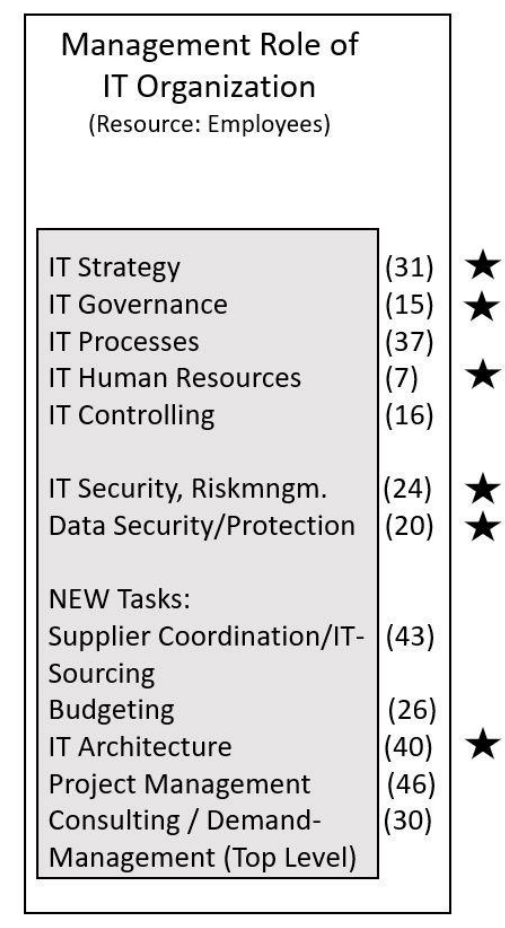

Companies ( $\mathrm{N}=79$ );

Numbers in ( ) in the chart show the mentioning in the job adds (max one per job add counted);

$\star$ Indicate tasks which resulted out of the coding process (table 1)

Fig. 3. Tasks of IT Organizations found in the pre-COVID-19 dataset.

Source: author's construction based on Krcmar (Krcmar 2015)

As further knowledge gain is not expected in regard to the research question, a full analysis of the second dataset from $28^{\text {th }}$ of October has not been performed. But the findings validate the relevance of the search phrases in table 1 .

\subsection{Specific findings regarding the influence of COVID-19}

As described in the section for coding the job advertisements have been searched for phrases and manual prove reading has been done for each reference before a counting has been included into the final calculation. Table 3 shows the findings. 


\begin{tabular}{|c|c|c|c|c|}
\hline $\begin{array}{l}\text { Literature } \\
\text { Review } \\
\text { Rank } \\
\text { (counts) }\end{array}$ & CIO Priorities during and after COVID-19 & $\begin{array}{l}\text { Relative } \\
\text { Counts } \\
\text { on 18th Feb. } \\
\text { (based on } \\
n=79 \text { ) }\end{array}$ & $\begin{array}{l}\text { Relative } \\
\text { Counts } \\
\text { on 28th Oct. } \\
\text { (based on } \\
n=63 \text { ) }\end{array}$ & Change in \% \\
\hline 1. $(n=4)$ & Digital collaboration & \multicolumn{3}{|c|}{ own visualisation } \\
\hline 2. $(n=3)$ & Information Security & $60.8 \%$ & $57.1 \%$ & $-3.6 \%$ \\
\hline 2. $(n=3)$ & Digitization of Business Model & $1.3 \%$ & $1.6 \%$ & $0.3 \%$ \\
\hline 2. $(n=3)$ & IT Strategy and Architecture & $29.1 \%$ & $22.2 \%$ & $-6.9 \%$ \\
\hline 3. $(n=2)$ & Customer Interface digital enhancement & $7.6 \%$ & $11.1 \%$ & $3.5 \%$ \\
\hline 4. $(n=1)$ & Data Security & $17.7 \%$ & $12.7 \%$ & $-5.0 \%$ \\
\hline 4. $(n=1)$ & Ensure business continuity & $2.5 \%$ & $3.2 \%$ & $0.6 \%$ \\
\hline 4. $(n=1)$ & Automation & $15.2 \%$ & $17.5 \%$ & $2.3 \%$ \\
\hline 4. $(n=1)$ & Risk Management & $5.1 \%$ & $1.6 \%$ & $-3.5 \%$ \\
\hline 4. $(n=1)$ & Governance & $3.8 \%$ & $4.8 \%$ & $1.0 \%$ \\
\hline 4. $(n=1)$ & Workforce & $0.0 \%$ & $3.2 \%$ & $3.2 \%$ \\
\hline 4. $(n=1)$ & Cost Control & $8.9 \%$ & $9.5 \%$ & $0.7 \%$ \\
\hline
\end{tabular}

Source: author's calculations based on structured content analysis

This qualitative method is very dependent from the researchers knowledge about information management practices and wording. Due to the low number of records in both datasets and the manual process of classifying the found search phrases the author believes that the results can give a indication regarding the change of the content of job adds, yet a statistical validity of the findings is questionable.

Regarding the number one priority for information management organisations which was "Digital collaboration", this Task of providing infrastructure or applications has never been mentioned in the job advertisements.

Yet, as also IT managers are users of such digital offerings and are under the same risk as anybody else in this time of the COVID-19 pandemic, the job offerings contain information about the future work environment of the IT top management candidates. These are shown in Table 4.

Table 4: Research results regarding personal work environment of the IT top management candidate

\begin{tabular}{|l|r|r|r|}
\hline Digital collaboration search results & $\begin{array}{l}\text { Relative Counts } \\
\text { on 18th Feb. } \\
\text { (based on } \\
\mathrm{n}=79)\end{array}$ & $\begin{array}{l}\text { Relative Counts } \\
\text { on 28th Oct. } \\
\text { (based on } \mathrm{n}=63 \text { ) }\end{array}$ & Change in \% \\
\hline Home office - standard & $1.3 \%$ & $9.5 \%$ & $8.3 \%$ \\
\hline Home office - temporarily / due to Covid-19 & $0.0 \%$ & $12.7 \%$ & $12.7 \%$ \\
\hline Home office - not possible & $0.0 \%$ & $6.3 \%$ & $6.3 \%$ \\
\hline Remote - if necessary & $1.3 \%$ & $0.0 \%$ & $-1.3 \%$ \\
\hline Remote -No & $0.0 \%$ & $1.6 \%$ & $1.6 \%$ \\
\hline
\end{tabular}




\section{Conclusion, proposals, recommendations}

After comparing the coded keywords in both datasets no significant change in requirements of tasks or structure of the job ads can be seen in the analysis. Which leads to the conclusion that recruiting departments within companies do not really collect requirements for top management IT positions through alignment with the business. The only traces Covid-19 has left in the job adds is that in some cases Home-office policies are mentioned.

The hypothesis and research question can only be proven through the literature research, structured content analysis only shows significant results in the area of home-office policies.

The main recommendation to the authors of IT management position job advertisements is to include current challenges in the requirements of the job description. It seems that most of the job advertisements are based on copy and paste and then either enriched or reduced in terms of content. Only few draw a picture about the impact and the opportunities of a job which might have a decisive advantage on finding the right person for the job in a candidate driven job market.

Future research should acquire more datasets in order to produce a higher statistical relevance. Then automation of classifying search results could help speeding up the process of coding, evaluation and calculation. The presented method could be a contribution to retrospectively analyse changes within the requirements of specific jobs profiles over time.

\section{References}

Barak, Israel (2020): Critical infrastructure under attack. Lessons from a honeypot. In Network Security 2020 (9), pp. 16-17. DOI: 10.1016/S1353-4858(20)30106-9.

Bates, Steve (2020): COVID-19. Insights for CIOs and IT executives. In KPMG, 2020. Available online at https://advisory.kpmg.us/insights/insights-for-your-role/cio-realinsights/covid-19-responses-it-executives.html, checked on 10/31/2020.

Bundesamt für Sicherheit in der Informationstechnik (BSI): Die Lage der IT-Sicherheit in Deutschland 2020. Available online at https://www.bsi.bund.de/SharedDocs/Downloads/DE/BSI/Publikationen/Lageberichte/Lagebe richt2020.pdf?_blob=publicationFile \&v=2, checked on 10/29/2020.

Chan, Y. E.; Sabherwal, R.; Thatcher, J. B. (2006): Antecedents and outcomes of strategic IS alignment. An empirical investigation. In IEEE Trans. Eng. Manage. 53 (1), pp. $27-47$. DOI: 10.1109/TEM.2005.861804. 
Chen, Chien-Fei; Zarazua de Rubens, Gerardo; Xu, Xiaojing; Li, Jiayi (2020): Coronavirus comes home? Energy use, home energy management, and the social-psychological factors of COVID-19. In Energy research \& social science 68, p. 101688. DOI: 10.1016/j.erss.2020.101688.

Digital transformation through the lens of COVID-19 | Deloitte Insights (2020). Available online at https://www2.deloitte.com/us/en/insights/topics/digital-transformation/digitaltransformation-COVID-19.html, updated on 10/31/2020, checked on 10/31/2020.

Durst, Michael (2007): Wertorientiertes Management von IT-Architekturen: Teubner.

Dwivedi, Yogesh K.; Hughes, D. Laurie; Coombs, Crispin; Constantiou, Ioanna; Duan, Yanqing; Edwards, John S. et al. (2020): Impact of COVID-19 pandemic on information management research and practice. Transforming education, work and life. In International Journal of Information Management 55, p. 102211. DOI: 10.1016/j.ijinfomgt.2020.102211.

Faulds, David J.; Raju, P. S. (2020): The work-from-home trend. An interview with Brian Kropp. In Business Horizons. DOI: 10.1016/j.bushor.2020.10.005.

Furnell, Steven; Shah, Jayesh Navin (2020): Home working and cyber security - an outbreak of unpreparedness? In Computer Fraud \& Security 2020 (8), pp. 6-12. DOI: 10.1016/S1361-3723(20)30084-1.

Grohmann, Helmut H. (2003): Prinzipien der IT-Governance. In HMD - Praxis der Wirtschaftsinformatik (40(232)), pp. 17-23.

Grover, Varun; Goslar, Martin D. (2015): The Initiation, Adoption, and Implementation of Telecommunications Technologies in U.S. Organizations. In Journal of Management Information Systems 10 (1), pp. 141-164. DOI: 10.1080/07421222.1993.11517994.

Hodgkinson, Stephen L. (1992): IT structures for the 1990s: organisation of IT functions in large companies. A survey. In Information \& Management 22 (3), 161-175.

IDG: CIO COVID-19 Impact Study - IDG. Available online at https://www.idg.com/toolsfor-marketers/cio-cv-19-impact-study/, checked on 10/31/2020.

Kim, Moon-Koo; Jee, Kyoung-yong (2007): Factors Influencing Strategic Use of Information Technology and Its Impact on Business Performance of SMEs. In ETRI J 29 (4), pp. 497-506. DOI: 10.4218/etrij.07.0106.0303.

King, William R.; Grover, Varun; Hufnagel, Ellen H. (1989): Using information and information technology for sustainable competitive advantage. Some empirical evidence. In Information \& Management 17 (2), pp. 87-93. DOI: 10.1016/0378-7206(89)90010-4.

Krcmar, Helmut (1991): Integration in der Wirtschaftsinformatik - Aspekte und Tendenzen. In : Integrierte Informationssysteme. Wiesbaden: Gabler Verlag (Schriften zur Unternehmens führung), p. 190.

Krcmar, Helmut (2015): Informationsmanagement. 6., überarb. Aufl. Berlin, Heidelberg: Springer Gabler.

Kumar, Aalok; Luthra, Sunil; Mangla, Sachin Kumar; Kazançoğlu, Yiğit (2020a): COVID19 impact on sustainable production and operations management. In Sustainable Operations and Computers 1, pp. 1-7. DOI: 10.1016/j.susoc.2020.06.001. 
Kumar, Shashank; Raut, Rakesh D.; Narwane, Vaibhav S.; Narkhede, Balkrishna E. (2020b): Applications of industry 4.0 to overcome the COVID-19 operational challenges. In Diabetes \& metabolic syndrome 14 (5), pp. 1283-1289. DOI: 10.1016/j.dsx.2020.07.010.

Malecki, Florian (2020): Overcoming the security risks of remote working. In Computer Fraud \& Security 2020 (7), pp. 10-12. DOI: 10.1016/S1361-3723(20)30074-9.

Marrone, Mauricio; Kolbe, Lutz M. (2011): Impact of IT Service Management Frameworks on the IT Organization. In Bus Inf Syst Eng 3 (1), pp. 5-18. DOI: 10.1007/s12599-010-0141-5.

Mayring, Philipp (2015): Qualitative Inhaltsanalyse. Grundlagen und Techniken. 12., aktualisierte und überarb. Aufl. Weinheim: Beltz (Beltz Pädagogik).

Meiler, Yannick (2020): Digital transformation, covid-19 crisis, digital transformation. In Pramuan Bunkanwanicha, Regis Coeurderoy, Sonia Ben Slimane (Eds.): Managing a Postcovid19 Era. ESCP Impact Papers. eBook. Paris: ESCP Research Institute of Management (ERIM), pp. 171-178, checked on 10/29/2020.

Moher, David; Shamseer, Larissa; Clarke, Mike; Ghersi, Davina; Liberati, Alessandro; Petticrew, Mark et al. (2015): Preferred reporting items for systematic review and metaanalysis protocols (PRISMA-P) 2015 statement. In Systematic reviews 4, p. 1. DOI: 10.1186/2046-4053-4-1.

Mouton, Francois; Coning, Arno de (2020): Covid-19: Impact on the Cyber Security Threat Landscape. Available online at https://www.researchgate.net/publication/340066124_COVID-

19_Impact_on_the_Cyber_Security_Threat_Landscape, checked on 10/28/2020.

PricewaterhouseCoopers (2020a): How technology leaders are responding to the COVID19 crisis. Available online at https://www.strategyand.pwc.com/de/de/implications-of-covid19/how-technology-leaders-are-responding-to-the-covid-19-crisis.html, updated on $10 / 31 / 2020$, checked on 10/31/2020.

PricewaterhouseCoopers (2020b): How technology leaders are responding to the COVID19 crisis. Available online at https://www.strategyand.pwc.com/de/de/implications-of-covid19/how-technology-leaders-are-responding-to-the-covid-19-crisis.html, updated on 10/31/2020, checked on 10/31/2020.

Roscher, Bjarne Erik; Brink, Norbert (2020): Tasks of IT managers: Emperical research based on job advertisements in Germany. In Submitted and accepted for 3rd International Conference on Applied Research in Management, Economics and Accounting. IARMEA Paris 2020.

Rüter, Andreas; Schröder, Jürgen; Göldner, Axel; Niebuhr, Jens (2010): IT-Governance in der Praxis. Erfolgreiche Positionierung der IT im Unternehmen. Anleitung zur erfolgreichen Umsetzung regulatorischer und wettbewerbsbedingter Anforderungen. Berlin, Heidelberg: Springer-Verlag Berlin Heidelberg (Xpert.press).

Samuels, Mark (2020): The CIO has a new set of priorities and problems. Here's what's on their to-do list. In ZDNet, 9/22/2020. Available online at https://www.zdnet.com/article/the- 
cio-has-a-new-set-of-priorities-and-problems-heres-whats-on-their-to-do-list/, checked on 10/31/2020.

Sandy Shen, Owen Chen, Julian Sun, Lily Mok, Arnold Gao, Deacon D.K Wan (2020): Coronavirus (COVID-19) Outbreak: Short- and Long-Term Actions for CIOs. CIOs need to increase resilience against future disruptions, and prepare for rebound and growth. Gartner Inc. Available online at https://www.gartner.com/en/doc/720647-covid-19-outbreak-shortand-long-term-actions-for-cios, checked on 10/31/2020.

Schweda, Christian M.; Schmidt, Werner (2014): Leichtgewichtiges, unternehmensspezifisches IT-Management. In HMD - Praxis der Wirtschaftsinformatik 51 (5), pp. 606-615. DOI: 10.1365/s40702-014-0062-8.

Szyperski, Norbert; Winand, Udo (1989): Informationsmanagement und informationstechnische Perspektiven. In Knut Bleicher, Eberhard Seidel, Dieter Wagner (Eds.): Organisation. Evolutionäre Interdependenzen von Kultur und Struktur der Unternehmung : Knut Bleicher zum 60. Geburtstag. Wiesbaden: Gabler, pp. 133-150.

Tallon, Paul P. (2014): A Process-Oriented Perspective on the Alignment of Information Technology and Business Strategy. In Journal of Management Information Systems 24 (3), pp. 227-268. DOI: 10.2753/MIS0742-1222240308.

Ward, John; Peppard, Joe (2002): Strategic planning for information systems by Joe Ward \& Joe Peppard. 3rd ed. John Wiley \& Sons (Wiley Series in Information Systems).

Weill, Peter; Ross, Jeanne W. (2004): IT governance: How top performers manage IT decision rights for superior results. In International Journal of Electronic Government Research (1(4)), pp. 63-67.

Weill, Peter; Woodham, Richard (2002): Don't Just Lead, Govern. Implementing Effective IT Governance. In SSRN Journal. DOI: 10.2139/ssrn.317319.

Wollnik, M. (1988): Ein Referenzmodell des Informationsmanagements. In Information Management 3 (3), pp. 34-43.

Zellmer, Gernot (1990): Risiko-Management. Berlin: Die Wirtschaft. 